\title{
Biogas production from submerged macrophytes - a case study of regional biomass potentials in Germany
}

\author{
Markus Röhl ${ }^{1 *}$ D, Sandra Roth ${ }^{1}$, Wolfgang Schütz ${ }^{2}$, Andreas Zehnsdorf ${ }^{3}$ and Carsten Herbes ${ }^{4}$
}

\begin{abstract}
Background: Utilization of energy crops for biogas production has been controversially discussed in Germany due to negative environmental effects and the "food vs. fuel" debate. This led to a search for alternative substrates focusing on material from landscape management measures. Aquatic biomass is harvested during water body management, yet it has not been considered for energy generation.

Methods: The information where and which amount of biomass is collected by aquatic de-weeding operations in rivers and lakes was gathered via a nationwide survey. In addition to that, the amount of aquatic plant biomass potentially available in water bodies was estimated exemplarily for the flowing waters of Baden-Württemberg-by using data from the European Water Framework Directive surveys.

Results: The survey revealed 172 locations of de-weeding operations in flowing waters and 93 in standing waters. These locations are concentrated in lowland rivers of the North German Plain as well as the Upper Rhine Plain. Standing water de-weeding operations were reported mainly from the foothills of the Alps. The overall amount of biomass harvested per year is 36,244 $t$ of fresh biomass. Taking into account missing data, a maximum of 100,000 $t$ of fresh biomass per year can be estimated for Germany. The case study on plant biomass de-weeded from waters in Germany revealed that only a small part of the total aquatic plant biomass is actually harvested.

Conclusions: The amount of biomass harvested and removed from water bodies in Germany is considerably lower than the harvest of other substrates from landscape management measures such as mowing of meadows or trimming of trees and hedges. However, larger amounts are accumulating locally, concentrated in some regions or at specific water bodies, e.g., reservoirs, for which regional value chains could be established. In order to make the exploitation of these local potentials economically viable, changes regarding the economic and technological framework are required.
\end{abstract}

Keywords: Aquatic macrophytes, Aquatic biomass, Biomass potential, Alternative substrates for biogas production, Water body management and maintenance, Aquatic de-weeding operations, Flowing water bodies, Standing water bodies, European Water Framework Directive

\footnotetext{
* Correspondence: markus.roehl@hfwu.de

${ }^{1}$ Hochschule für Wirtschaft und Umwelt Nürtingen-Geislingen, Institut für Landschaft und Umwelt (ILU), Sigmaringer Strasse 14, 72622 Nürtingen, Germany

Full list of author information is available at the end of the article
}

(C) The Author(s). 2019 Open Access This article is distributed under the terms of the Creative Commons Attribution 4.0 International License (http://creativecommons.org/licenses/by/4.0/), which permits unrestricted use, distribution, and reproduction in any medium, provided you give appropriate credit to the original author(s) and the source, provide a link to the Creative Commons license, and indicate if changes were made. 


\section{Background}

Due to climate change, limited fossil fuels, and rising energy demand and prices, renewable energy from the wind, the sun, water, and biomass has been strongly promoted in Germany. Since the introduction of the Renewable Energy Act (REA) in 2000, the generation of electricity from renewable resource has been increasing continuously and so has the installation of biogas plants [1]. However, the cultivation of energy crops, especially maize, for the utilization in biogas plants is often discussed controversially. Main points of criticism are environmentally adverse cultivation methods and extensive land consumption [2]. This has led to a search for alternative substrates, such as material from landscape management [3].

Regardless of whether land management material is needed to achieve German renewable energy targets, such substrates can put pressure off agricultural production sites [2,3]. There is still a huge and unused potential of biomass from landscape management basically suitable for energetic use. However, the sustainable and economically viable use of this type of biomass is problematic due to its partly high water content as well as the high efforts for harvesting and logistics. Up to now, few studies have shown that aquatic biomass from water body management and maintenance is a suitable substrate for biogas generation.

The growth of aquatic plants is basically influenced by the streamflow regime, the stability of the sediment, the availability of nutrients, and especially sunlight [4-6]. Providing favorable conditions, aquatic plants can grow excessively. Mass occurrence of aquatic plants in rivers can reduce the river flow considerably [7] and lead to impairments of energy generation from hydropower, as well as threaten flood protection. In lakes, water sports and recreational activities, like fishing or bathing, can be hindered. Thus, biomass has been removed mechanically for decades in Central Europe [8, 9]. Mass occurrence of aquatic plants can be found mainly in anthropogenic disturbed waters. Here, shallow water depths and lack of shading of the waters are significant factors. Reduction of nutrient inputs therefore does not prevent mass occurrence at first. Especially for flood protection reasons, rivers will have to be de-weeded in future.

Various studies have shown that the aquatic macrophyte biomass is basically suitable as a substrate in biogas plants $[10,11]$. The biogas yield depends on various factors: In addition to the mixture of aquatic plant species in the biomass and the harvesting time [12, 13], biomass logistics (harvested amount, storage, transport) are highly relevant. Freshly harvested biomass contains a very high amount of water, which is decreasing quickly while stored on land $[14,15]$. The time for storage and transport affects the entire process of the energetic use of these substrates. In summary, the substrates have high nutrient content and low concentrations of heavy metals at harvest time [13]. The storage and ensiling of the substrates is possible under certain conditions [10,11]. Thus, the basic suitability of the substrates for biogas production has been demonstrated but is not yet practiced on a large scale.

To further evaluate the feasibility of using aquatic plant biomass as a substrate for biogas production, it is necessary to know the location and amount of biomass that is currently collected during aquatic de-weeding operations. Data for a few single water bodies can be found, but a comprehensive overview does not yet exist for the rivers and lakes in Germany. Thus, the aim of this study was to investigate all de-weeding operations and the amount of aquatic plant biomass harvested in Germany.

The study focused on de-weeding by boat, such as mowing boats or amphibious boats (Fig. 1). Mowing from land by excavators or tractors with a mowing bucket, which is usually used for ditches and trenches, was left out for the following reason: while mowing with mowing buckets, often the beds of ditches are cleared, too. The plant material could then be mixed with high amounts of sediment, and this would a priori question the usability of such substrates for biogas production.

In addition to collecting data on the fresh biomass quantities that are harvested today, an analysis of the amount of biomass of aquatic plants potentially available in the water bodies (standing crop) could widen the view on the quantities that could be harvested in the future. Reliable sources for the production of biomass of water plants for a region or a state in Germany could not be found. Therefore, a second goal of this study was to estimate this amount by using existing data of the distribution and quantities of macrophytes.

\section{Methods}

Research and compilation of de-weeding operations data in flowing and standing waters

There are no official statistics on aquatic de-weeding operations and the fresh biomass harvested in Germany, so

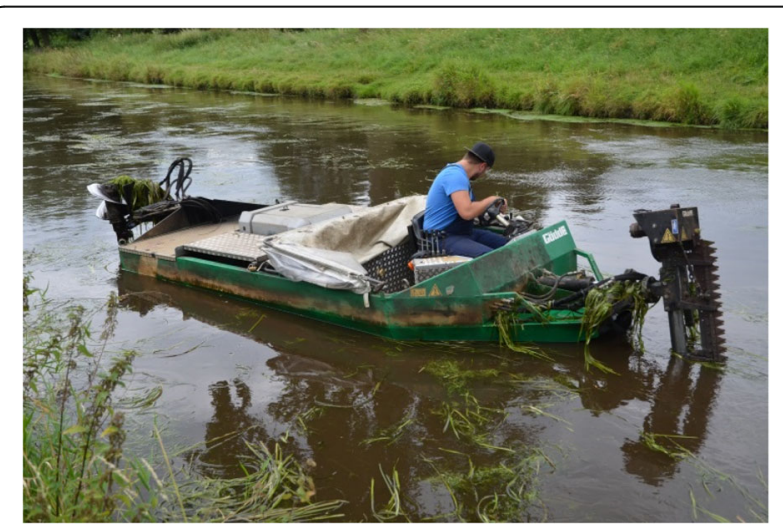

Fig. 1 Mowing boat on the river Niers (North Rhine-Westphalia, Germany) 
this information had to be collected firsthand from institutions responsible for water body management and maintenance in Germany. Due to the federal structure in Germany, there are no uniform administrative structures within the water authorities. Therefore, for data collection, the responsible authorities and offices were first researched. Afterwards, a semi-structured questionnaire was sent to those contacts via e-mail between January and May 2015. The following items in the survey were relevant for achieving the abovementioned objectives:

- Name, type, and location of the de-weeded water body

- Reasons for the aquatic de-weeding

- Frequency of the aquatic de-weeding

- Amount of aquatic plants collected

- Current path of utilization or disposal of the biomass

The contact information and responses were collected in a database. The spatial data was captured and analyzed in a geographic information system (GIS). Unfortunately, a representative spatial distribution of responses within Germany could not be achieved with the e-mail survey, even though the response rate was $36.3 \%$. To increase the coverage, non-repliers were subsequently interviewed by phone, especially federal state authorities and regional water boards. The results were supplemented with data from reports of de-weeding operations in newspapers, using the databases "WISO" and "Library Pressdisplay," along with the Internet. With these complementary means of data acquisition, the response rate could be increased to $50 \%$ (Table 1 ).

Table 1 Results of the survey of water bodies de-weeded in Germany

\begin{tabular}{|c|c|c|}
\hline Type of institution & Contacts & Responses \\
\hline Federal authorities & 40 & 25 \\
\hline Federal state authorities and companies & 123 & 84 \\
\hline District administrations & 242 & 151 \\
\hline Municipal administrations & 377 & 86 \\
\hline Municipal companies & 36 & 15 \\
\hline $\begin{array}{l}\text { Regional water boards and joint water } \\
\text { management authorities }\end{array}$ & 258 & 201 \\
\hline $\begin{array}{l}\text { Associations (esp. fishing, nature conservation, } \\
\text { recreation) }\end{array}$ & 43 & 16 \\
\hline Planning and engineering offices & 7 & 3 \\
\hline $\begin{array}{l}\text { Private companies (esp. water body } \\
\text { maintenance, production of energy, } \\
\text { recreation, fishing) }\end{array}$ & 79 & 26 \\
\hline Universities and other scientific institutions & 12 & 1 \\
\hline Total & 1217 & 608 \\
\hline
\end{tabular}

\section{Estimation of biomass potentials in flowing waters}

For an indication of the approximate order of magnitude of biomass potentially available in flowing waters in a region (standing crop), data of the European Water Framework Directive (WFD) surveys were used. This data exists nationwide and is managed by the federal states.

The WFD lists aquatic macrophytes as one of the biological quality elements required for assessing the ecological status of surface water bodies [16]. The monitoring sites in flowing waters are located in a way that they represent the surface water body, which is a stretch of flowing water that is as uniform as possible. The sites generally have a standard length of $100 \mathrm{~m}$ and are surveyed by wading. Among master data, such as the streamflow and width of the reach (each classified), the "plant mass" of each species is estimated by eye, using a 5 -level estimation scale ( $1=$ rare, $2=$ occasional, $3=$ frequent, $4=$ abundant, $5=$ very abundant), which refers to Kohler and Janauer [17]. Additionally, the estimation of the total cover of all aquatic plants (plant cover) in the reach in percent is mandatory in most of the federal states. The WFD data cannot only be used for ecological assessment, but also for the analysis of the spatial distribution and indirectly for the estimation of the water plant biomass growing in the monitoring reaches. Thus watercourses and regions with high macrophyte biomass can be identified, and the results of the reaches could be extrapolated to the total length of flowing waters in a region.

In this study, the WFD data of the federal state of Baden-Württemberg was analyzed exemplarily. BadenWürttemberg is located in southwestern Germany and contains central mountain areas and lower regions in the Rhine Valley. Records for 549 monitoring reaches from the year 2012 were provided by the State Institute for the Environment, Measurements and Nature Conservation Baden-Württemberg (LUBW). This data is representative for 158 surface flowing water bodies (according to the WFD), which in Baden-Württemberg are based on water catchment areas, and not on individual sections of flowing waters, as in other federal states.

The mapping methods in the WFD are based on an ordinal scale of coverage. This is typical for scales in vegetation science. The methodology allows only indirectly the determination of fresh or dry biomass quantities. According to Janauer and Heindl however, there is a direct correlation between Kohler's "Plant Mass Estimates" (PME) and the plant biomass. To overcome the problems related to the analysis of ordinal data [18], Kohler's PME were transformed into "plant quantities" (representing a cubic measure), using the function $y=x^{3}$, where $y=$ plant quantity and $x=$ PME [19]. These "plant quantities" have never been related experimentally to plant dry biomass (in gram dry matter per square 
meter). However, the relation between plant cover and dry or fresh biomass has been investigated, albeit only in very few cases [6]. The biomass also depends on a few other parameters (for example, water depth and different structure of aquatic plants). Nevertheless, a derivative of the biomass of values to plant cover seems possible, although there should not be very high expectations on the accuracy of such a relationship [6].

Since the estimate of plant cover was available only for a subset of monitoring reaches of the 2012 WFD dataset for Baden-Württemberg $(n=118)$, the relationship between coverage and summarized or total PME (TPME) per reach was assessed for all monitoring reaches by means of a correlation analysis $\left(r^{2}=0.79, p=0.0001\right.$, [6]). The TPME were then assigned to mean cover levels (in percent) in five stages, as shown in Table 2.

The relationship between plant cover and dry biomass was estimated based on data measured by Krausch [20] using a simple linear model. Sites dominated by aquatic mosses showed significantly lower biomass levels at similar plant covers than sites dominated by aquatic vascular plants (Table 3). Thus the dry matter (DM) per square meter for each monitoring reach was calculated with the regression coefficient $\beta=3.25 \mathrm{~g} \mathrm{DM} / \mathrm{m}^{2}$ for sites dominated by aquatic vascular plants and $\beta=1.41$ $\mathrm{g} \mathrm{DM} / \mathrm{m}^{2}$ for sites dominated by aquatic mosses $\left(\mathrm{DM}_{\mathrm{m}}{ }^{2}\right.$ $\left[\mathrm{g} / \mathrm{m}^{2}\right]=\beta\left[\mathrm{g} / \mathrm{m}^{2}\right] *$ mean plant cover ${ }_{\text {reach }}[\%]$; for both: $\left.r^{2}=0.98, p<0.001\right)$.

These data were extrapolated to the known area per monitoring reach $\left(\left[\mathrm{DM}_{\text {reach }}=\mathrm{DM}_{\mathrm{m}}{ }^{2} \times\right.\right.$ standard length $\mathrm{reach} \times$ mean width ${ }_{\text {reach }}$, with $\mathrm{DM}_{\text {reach }}=$ dry matter in grams; standard length ${ }_{\text {reach }}$ and width reach $_{\text {in meters). }}$ Assuming that the 549 monitoring reaches are representative for the macrophytic colonization of rivers and brooks in Baden-Württemberg, the sum of all dry weights per reach was extrapolated to the total length of flowing waters of Baden-Württemberg. The information on the total length of flowing water bodies was extracted out of official geographical data provided by the LUBW for Baden-Württemberg (the AWGN-Amtliches Digitales Wasserwirtschaftliches Gewässernetz).

Table 2 Total plant mass estimates (TPME, as summarized PME) with assigned mean cover level

\begin{tabular}{ll}
\hline Total plant mass estimates (TPME) & Mean cover [\%] \\
\hline$<60$ & 2.5 \\
$60-100$ & 5.0 \\
$100-180$ & 30.0 \\
$180-340$ & 75.0 \\
$>340$ & 100.0 \\
\hline
\end{tabular}

Table 3 Relationship between plant cover and biomass of sites dominated by aquatic mosses and sites dominated by phanerogamic macrophytes (Ranunculetum) in a river according to Krausch [20]

\begin{tabular}{lll}
\hline $\begin{array}{l}\text { Mean } \\
\text { cover } \\
{[\%]}\end{array}$ & $\begin{array}{l}\text { Biomass }\left[\mathrm{g} \mathrm{DM} / \mathrm{m}^{2}\right] \\
\text { dominated by mosses }\end{array}$ & $\begin{array}{l}\text { Biomass }\left[\mathrm{g} \mathrm{DM} / \mathrm{m}^{2}\right] \text { dominated by } \\
\text { phanerogamic macrophytes }\end{array}$ \\
\hline 2.5 & 3.25 & 7.6 \\
15.0 & 19.0 & 45.0 \\
37.5 & 52.5 & 112.5 \\
62.5 & 87.5 & 187.5 \\
87.5 & 125.0 & 300.0 \\
\hline
\end{tabular}

\section{Results and discussion}

Biomass potential from de-weeded waters in Germany Spatial distribution over Germany

The results of the nationwide survey of de-weeding operations in Germany are shown cartographically in Fig. 2 for flowing waters and Fig. 3 for standing waters. There are 172 spots for de-weeding operations in flowing waters and 93 in standing waters. Some spots on the map represent more than one body of water. It should however be noted that the questionnaire was completed for a set of water bodies maintained by an institution, especially when only the total yearly amount of fresh biomass (FM) harvested was known for all the water bodies managed by that particular institution.

The Figs. 2 and 3 show considerable differences in mowing activities and the yearly amount of FM in the spatial distribution between flowing and standing waters.

Rivers de-weeded by boat are mostly located in the lowlands, especially in the natural regions North German Plain and Upper Rhine Plain, where the streamflow of the rivers is low. For the Central Uplands and the Alpine Foreland, de-weeding operations were only reported for the Danube and the Rhine and their tributaries.

Referring to the federal states, de-weeding operations and the biomass harvested are concentrated in MecklenburgWestern Pomerania, Lower Saxony, and SchleswigHolstein.

Standing waters, de-weeded by boat, were mainly reported for the Alpine Foreland and the Central Uplands as well as for the transition from the Central Uplands to the North German Plain. These water bodies are often of artificial origin, such as reservoirs, excavation pools, or ponds in parks.

The gathering of information was problematic, since the data is not centrally captured and sometimes not even recorded at all. Furthermore, it can be assumed that the database for standing waters has more gaps than for flowing waters. Often, tenants, like fishing associations or operators of camping sites and bathing areas are responsible for the maintenance of standing water bodies such as ponds and 


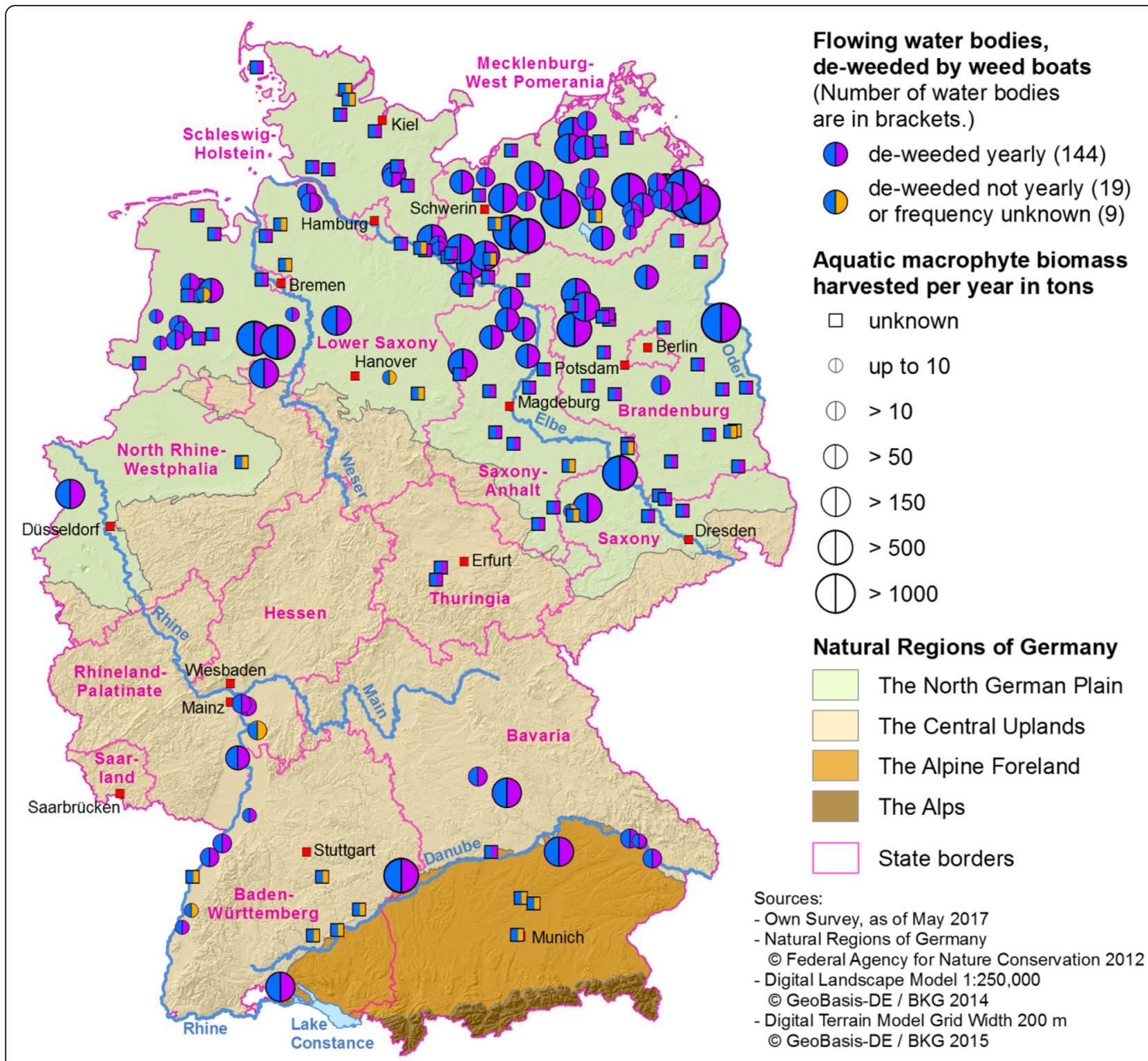

Fig. 2 De-weeding operations in flowing water bodies in Germany

lakes. Obtaining contact information from them was much more difficult than from authorities officially responsible for flowing waters. To remedy this, district and municipal administrations were requested to forward the survey to relevant contact persons-an intermediate step with varied success.

\section{Amount of aquatic biomass harvested}

In our survey, the amount of biomass was stated either in units of volume or weight, referring partly to fresh biomass, or more or less dried and compressed biomass.

The fresh biomass (FM) is often stored on-site for a certain time after removal and weighed later, e.g., when passed to a composting plant. During this time, the pile of biomass loses a significant amount of water and thus weight and volume, respectively. The loss of water consists of adhesive water and water contained in the plants. The latter ranges between $85 \%$ and $90 \%$ for aquatic plants $[12,14]$.

To convert units of weight into volume (and vice versa), a value for density is needed, which depends on the seasonal time of harvesting and the mixture of water plant species. For drained and compressed samples of the western waterweed (Elodea nuttallii (Planch.) St. John), an average density of $350 \mathrm{~kg} \mathrm{FM} / \mathrm{m}^{3}$ was determined [21]. Analysis of mixed samples from the river Niers in North Rhine-Westphalia resulted in an average 


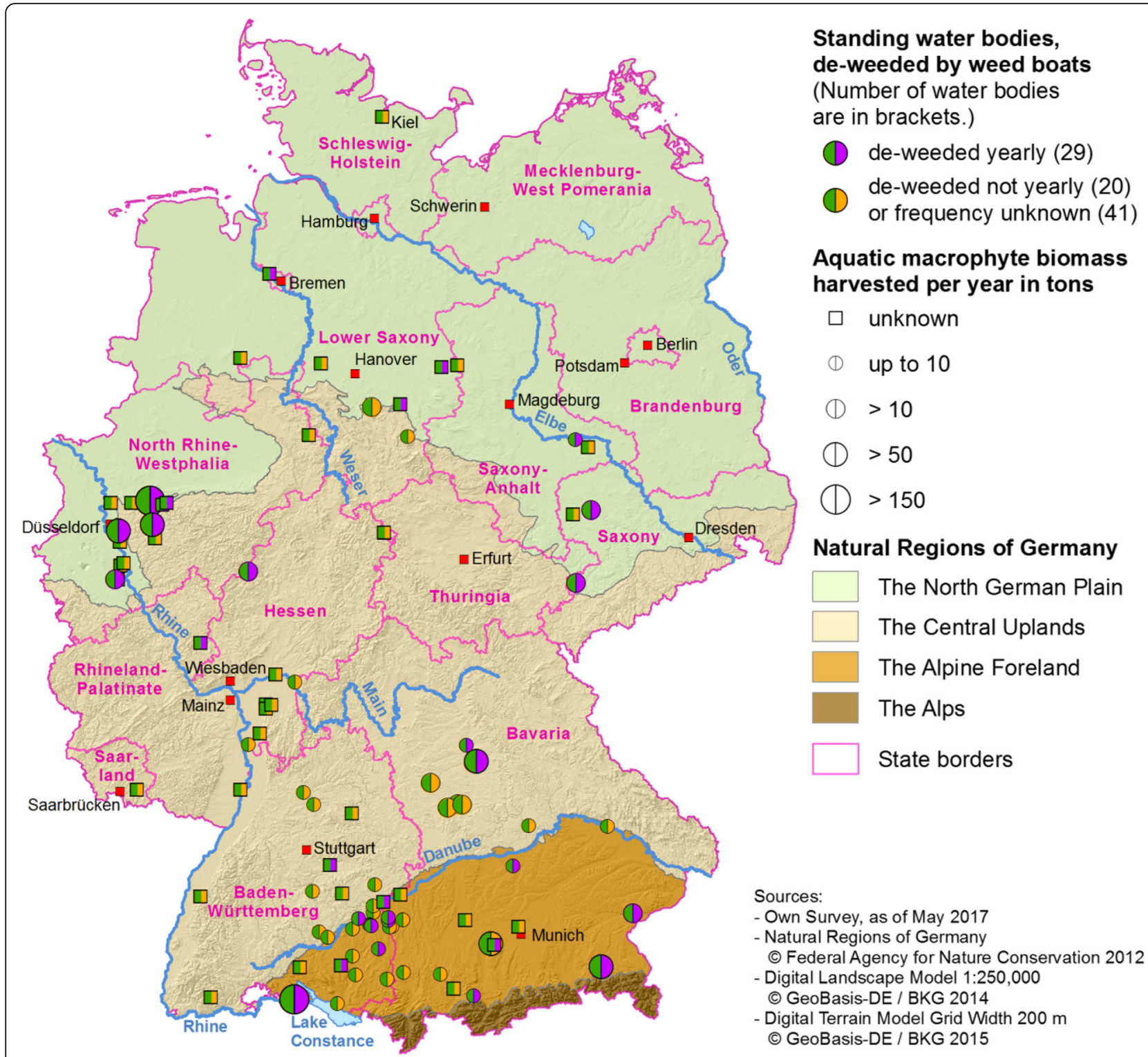

Fig. 3 De-weeding operations in standing water bodies in Germany

density of $250 \mathrm{~kg} \mathrm{FM} / \mathrm{m}^{3}$ [14]. Another study showed even lower density rates [22].

The amounts of biomass were mostly given in units of weight, so the units of volume were converted with an average density of $250 \mathrm{~kg} \mathrm{FM} / \mathrm{m}^{3}$ into tons. The total sum of fresh biomass harvested per year that was reported in this study amounts to 36,244 t FM/a.

However, quantitative data was only provided for $52 \%$ of the de-weeding operations in flowing waters and for $44 \%$ in standing waters. Considering the missing quantitative data and the questionnaire/interview response rate of $50 \%$, the total biomass of aquatic plants to be harvested in Germany can be estimated to two or three times higher than the total amount (minimum of 72,000 t FM/a and a maximum of 100,000 t FM/A) reported in this study.

The amount of fresh biomass harvested is differing considerably depending on the types of water bodies. For standing waters, small amounts of biomass, less than $10 \mathrm{t} /$ year, are frequently reported (Fig. 4). These bodies of water are often de-weeded to enable bathing, fishing, or recreational boating. Therefore, only small areas have to be de-weeded.

In flowing waters, de-weeding is necessary to guarantee a certain water runoff to ensure flood protection. Thus, the whole water body has to be de-weeded on a certain length, leading automatically to larger quantities of harvest. More than $50 \%$ of the records for flowing 


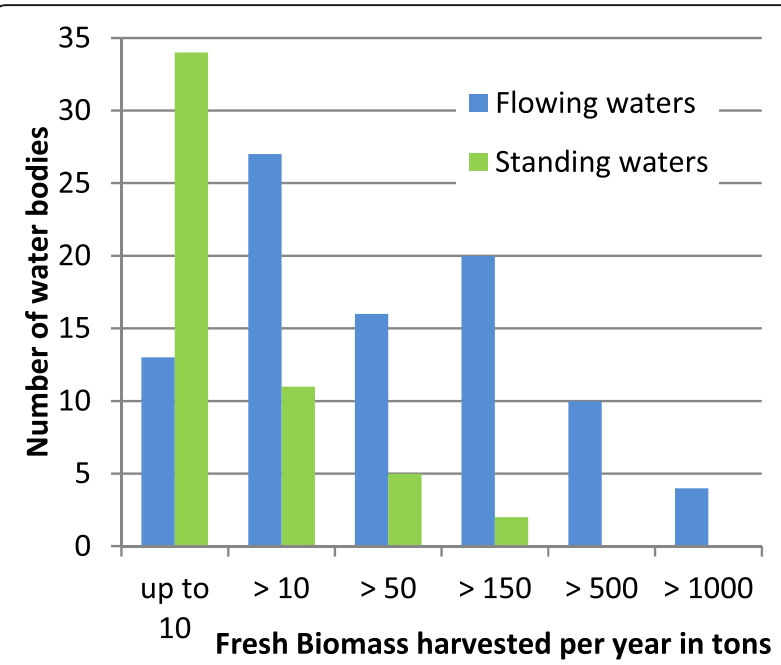

Fig. 4 Biomass harvested by de-weeding boats in flowing and standing waters in Germany

waters are above $50 \mathrm{t} /$ year. In some cases, amounts above $1000 \mathrm{t}$ /year were reported as a sum for several rivers in the area of one water maintenance authority.

For both standing and flowing waters, these amounts of biomass are only a small proportion of the plant biomass growing in the entire water bodies.

For the shallow water zone (depth up to $6 \mathrm{~m}$ ) of the Cospudener See, a post-mining lake in the federal state of Saxony with a size of approx. $440 \mathrm{ha}$, an amount of approx. $3000 \mathrm{t}$ FM/a of total fresh biomass was estimated, using data originated from diving explorations and determination of biomass in August 2016 [13]. The amount of biomass harvested for standing waters recorded in the survey is between 1 and $250 \mathrm{t} \mathrm{FM/a,} \mathrm{with}$ an average amount of $24 \mathrm{t} \mathrm{FM/a.}$

In the Kemnader See, a reservoir in the river Ruhr in the federal state of North Rhine-Westphalia, only between 10 and $25 \%$ of the biomass are removed by deweeding [22].

For a stretch of $27 \mathrm{~km}$ of the river Schutter in the federal state of Baden-Württemberg, characterized by slow stream velocity and a mainly muddy riverbed, a dry mass of $39 t$ was estimated for summer 2011. With a supposed dry matter content of $10 \%$, this would result in a fresh mass of $14 \mathrm{t}$ per $1000 \mathrm{~m}$ [6]. In the survey, $1 \mathrm{t}$ of fresh mass harvested was reported for summer 2013 for a similar stretch of $500 \mathrm{~m}$ downriver, hence only $14 \%$ of the total biomass.

There are some more aspects of aquatic macrophyte biomass, which could not be analyzed quantitatively in this study. In addition, there are plants that could, for technical reasons, not be harvested or gathered during the de-weeding process. For example, plants may not have been collected because they were much lower than the mowing boat's cutting depth, or they were suppressed by the bow wave of the boat. Alternatively, plants that did get mowed-such as water-starworts (Callitriche genus)-may have gotten stuck at the embankments or drifted under collecting gear and thus not recorded. For the river Niers, $10-20 \%$ of the mowed water plants get stuck at the riverbanks and about $25 \%$ are not caught at the collection facilities [14].

During rapid water runoff, after storms, or naturally in fall, remaining water plants would root out and catch up as flotsam at rakes of dams or wash ashore at lakes and ponds. Between 500 and $1200 \mathrm{~m}^{3}$ of flotsam is removed on monthly average during the month of September to December at the rakes of the hydroelectric power station of the Harkortsee, another reservoir in the river Ruhr [23]. Thus, it must be assumed that this biomass is more contaminated by garbage and driftwood.

\section{Frequency of de-weeding}

The growth of biomass in water bodies is fluctuating yearly, e.g., depending on the progression of temperature and streamflow during the year [4], resulting in a yearly fluctuating amount of biomass harvested. In some years, de-weeding can even be omitted.

For the river Hegauer Aach in Baden-Württemberg, a time series was provided with the questionnaire. Here, the amount of fresh biomass harvested varied from 756 up to $5490 \mathrm{~m}^{3}$ for the years 2004 to 2015 (factor of 7) [15].

For half of the records of standing waters, the information of the frequency of de-weeding-yearly or not yearly-was not available (Table 4 ). That applies mainly to records extracted from press articles. Those incidents are often reported as single events. Even if articles for several years for a special water body were found or the reference that a special water body is de-weeded "again," it could not be assumed, that this means yearly de-weeding. Nevertheless, the percentage of standing water bodies not deweeded yearly is higher as compared to flowing waters.

This can also be explained by the reasons for de-weeding and the type of institution initiating the de-weeding. Tenants of ponds and lakes, like fishing associations or operators of camping sites and bathing areas often do not have the financial means for de-weeding initiatives and have to seek (financial) help from their local municipality. Those de-weeding operations have to be approved by district administrations, especially from the perspective of nature conservation.

The obligation for maintenance of flowing water bodies is assigned to the responsible authorities, like federal state authorities or regional water management authorities, by law. These institutions are equipped with the 
Table 4 Frequency of de-weeding in flowing and standing waters in Germany

\begin{tabular}{lllll}
\hline $\begin{array}{l}\text { Type of water } \\
\text { body }\end{array}$ & $\begin{array}{l}\text { Total number of water } \\
\text { bodies de-weeded }\end{array}$ & $\begin{array}{l}\text { Number of water bodies } \\
\text { de-weeded yearly }\end{array}$ & $\begin{array}{l}\text { Number of water bodies not } \\
\text { de-weeded yearly }\end{array}$ & $\begin{array}{l}\text { Number of water bodies, frequency of } \\
\text { de-weeding unknown }\end{array}$ \\
\hline Flowing water bodies & 172 & 144 & 19 & 9 \\
Standing water bodies & 93 & 30 & 22 & 41 \\
\hline
\end{tabular}

necessary capital and manpower. Their de-weeding activities are conducted within the scope of proper water maintenance practice.

\section{Utilization of aquatic biomass harvested}

Multiple answers were provided for the utilization and disposal of plant biomass, respectively. Composting is dominating in the questionnaire with $72 \%$ of the cases. In $20 \%$ of the cases, the biomass is transported to a landfill or left on-site. In two cases, the biomass was not even removed. Only in three cases was the (attempted) utilization listed as "biogas plant." Significantly, more than $90 \%$ of the harvested biomass is therefore not used for bioenergy. The reason for this is mainly due to the unclear legal status of substrates from de-weeding operations in water bodies according to the German Renewable Energy Act (REA). The second reason is certainly the lack of experience for storage and ensiling of the substrates.

\section{Regional biomass potentials in flowing waters}

According to the analysis of the dataset from the European Water Framework Directive (WFD) for the federal state of Baden-Württemberg, 52\% of the 549 monitoring reaches were moss-dominated. Vascular plants were predominant in $42 \%$, and $6 \%$ of the reaches lacked macrophytic vegetation. The degree of coverage derived from the estimated total amount of macrophytes (TPME) is equal or less than $5 \%$ in more than half of the 549 reaches and above $50 \%$ in only $16 \%$ of the reaches, representing approx. dry weights between zero and $325 \mathrm{~g} / \mathrm{m}^{2}$.

A submersed mass stock is usually formed by one or more species belonging to five submersed vascular plant genera: pondweeds (Potamogeton), water crowfoots (Ranunculus subgenus Batrachium), water-starworts (Callitriche), waterweeds (Elodea), and watermilfoils (Myriophyllum). However, no species from these five genera was present in more than $13 \%$ of the 549 reaches. As a consequence, a quantitatively significant biomass is only to be expected in about one third of the reaches. These reaches are located mainly in the Upper Danube and its tributaries from the Jurassic of the Swabian Alb and from the moraine landscape in Upper Swabia as well as in the lower reaches of many tributaries of the Rhine River (Fig. 5). These findings are in line with the results of our survey. De-weeding operations in rivers in Baden-Württemberg were reported especially in these regions (Fig. 2).
Summing up the biomass per reach $\left(\mathrm{DM}_{\text {reach }}\right)$ for all monitoring reaches in Baden-Württemberg, a total of $34.77 \mathrm{t}$ dry matter has been calculated. The dataset of the AWGN (Amtliches Digitales Wasserwirtschaftliches Gewässernetz) of the federal state of Baden-Württemberg (as of March 2017) contains more than 18,400 watercourses with a total length of $38,600 \mathrm{~km}$. Based on this total length, the entire biomass (standing crop) in the flowing waters of Baden-Württemberg is about 24,500 $t$ dry matter-respectively 240,000 to $360,000 \mathrm{t}$ fresh matter (with $10-7 \%$ dry matter content).

The deduction of mean plant cover and dry matter per reach from WFD data is subject to numerous shortcomings and uncertainties. This also applies to the estimation of the entire biomass of aquatic plants in BadenWürttemberg.

Even though the monitoring sites were investigated in a period between mid-June and the beginning of October 2012 (June, 82 sites; July, 155; August, 158; September, 147; October, 7), the amount of total biomass must be estimated for a certain point in time. It is therefore not an annual estimate of the amount of biomass harvested and removed. An anew growth of biomass after de-weeding is not taken into account.

The sites were classified only in the two categoriesdominated by mosses or dominated by aquatic vascular plants. The latter were not further differentiated according to the dominant species of aquatic vascular plants. Some plant stocks had higher amounts of dry matter, for example, numbers up to $1,3 \mathrm{~kg} / \mathrm{m}^{2}$ dry matter were measured for single-species stands of western waterweed (Elodea nuttallii) [12].

Furthermore, the relation between summarized plant quantities (TPME) and mean cover should be verified with WFD data of federal states, where the mean cover must be estimated on site.

The amount extrapolated to the federal state of BadenWürttemberg varies with the used total length of the flowing waters. The AWGN is continuously updated, so the numbers change continuously as well. The reference scale of the AWGN is $1: 10,000$. Only permanently flowing waters with a length greater than $500 \mathrm{~m}$ are registered [24]. Information on the mean width and depth of the watercourses is not provided. However, the AWGN is this database for the WFD surveys in Baden-Württemberg. The monitoring sites are located in brooks with a mean width of $1 \mathrm{~m}$ up to rivers with a mean width of $300 \mathrm{~m}$. 


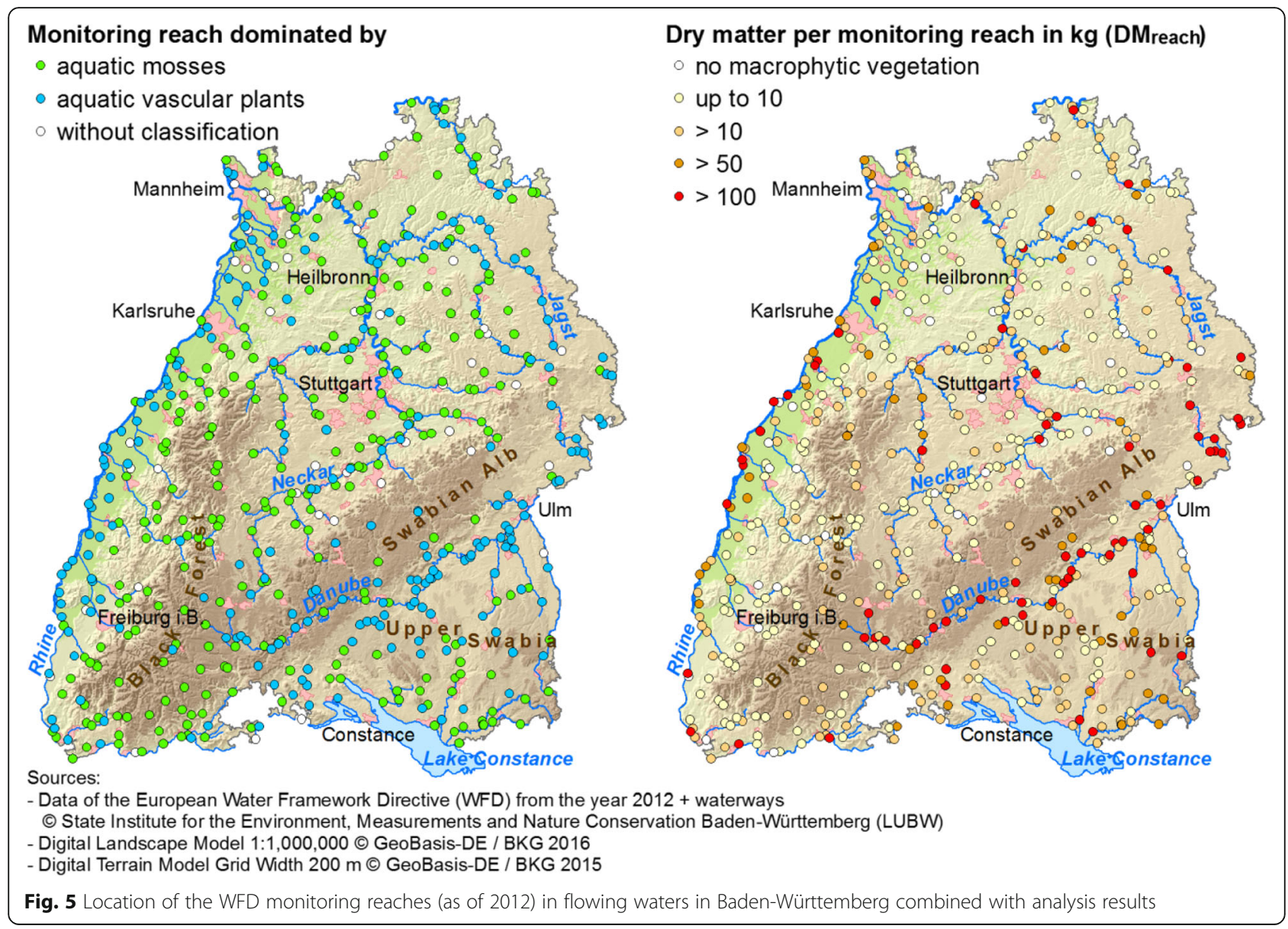

Despite being a rough estimate, the results show that the biomass removed from water bodies is only a fraction of the entire biomass in a region. The survey revealed de-weeding operations for 12 rivers in the federal state of Baden-Württemberg. Data for the amount could only be ascertained for seven of these rivers, resulting in a total amount of fresh biomass harvested and removed of $1269 \mathrm{t} \mathrm{FM/a.} \mathrm{Even} \mathrm{if} \mathrm{the}$ missing data of the survey is taken into account, the biomass removed is only approx. $1 \%$ of the entire biomass of aquatic plants in flowing waters in BadenWürttemberg.

To make statements for other federal states or the whole of Germany, the WFD data of the other federal states must be analyzed. This would imply a considerable effort, as the data is kept decentral and in different formats.

\section{Conclusions}

The study described provides for the first time a comprehensive overview of the de-weeding operations in Germany. An indication of the spatial distribution and a magnitude of the amount of fresh biomass harvested and removed from water bodies could also be given.
The total amount of biomass harvested and removed in Germany has been estimated at 100,000 $t$ fresh matter per year. This is little in comparison to other substrates from landscape management measures such as mowing of meadows or trimming of trees and hedges $[1,3]$. However, larger amounts are accumulating locally in some regions, e.g., for reaches of rivers de-weeded in the federal state of Mecklenburg-Western Pomerania. An energetic use of the harvested biomass is therefore currently only possible in these regions. Other possible sites for biomass use are the reservoirs and mining lakes with mass occurrences of submerged macrophytes. Locally larger amounts of biomass accumulate here. Another obstacle for the energetic use is the yearly fluctuation of the biomass production, e.g., depending on the progression of temperature and streamflow over the year.

The amount of biomass potentially available in the water bodies (standing crop) was exemplarily estimated for the rivers and brooks in the federal state of Baden-Württemberg by analyzing data of the European Water Framework Directive (WFD) surveys. An amount of 240,000 to $360,000 \mathrm{t}$ fresh matter only for this federal state has been calculated. It can be assumed, that the WFD surveys provide representative 
data of the colonization of water plants in flowing waters in this federal state: The monitoring sites are spread like a net over a region and are located in brooks with a mean width of $1 \mathrm{~m}$ up to rivers with a mean width of $300 \mathrm{~m}$. For standing waters, such data is not available, as only standing water bodies with an area larger than 50 ha have to be officially surveyed. This applies only to 24 lakes of natural and artificial origin in Baden-Württemberg [25].

Yet, the example of Baden-Württemberg shows, that referring to the total amount of biomass of macrophytes in the flowing and standing water bodies in Germany, the potential for an energetic use must be considerably higher than the one based on current de-weeding operations. Climate change may severely alter the risk of hydrological extremes over large regional scales [26]. This may increase the need to secure the flow of running waters.

With changes in the economic and technological framework (different mowing technology, usability of the substrates, etc.) this potential could be exploited to a larger extent. This applies especially to standing water bodies with mass occurrences of aquatic plants, which are deweeded only partly due to financial reasons [22, 23, 27].

For recent de-weeding operations, regional value chains for the energetic use of macrophytes should be established already today-especially for regions with hot spots of de-weeding operations (Mecklenburg-Western Pomerania, Lower Saxony) or single sites with huge amounts of biomass harvested (e.g., reservoirs in the river Ruhr, river Niers-all in North Rhine-Westphalia). Basically, the interest of local biogas operators in using the harvested biomass is high. In our survey, $30 \%$ of respondents said they would consider using biomass in biogas plants. This is in contrast to the previously low use of the substrates. The reasons for this were, in addition to the lack of experience with the storage of the material, above all the unclarified status of the substrates.

Still, changes in the legal framework are necessary. Since most of the biogas plants in Germany run on renewable resources, it is important to clarify the legal status of substrates from de-weeding operations in water bodies, especially whether they are renewable resources according to the German Renewable Energy Act (REA) or not [28]. Algae and submerged macrophytes are not part of the list of substrates from landscape management of the REA. The operators of biogas plants endanger their bonus for renewable raw materials or the approval of their plant, if they use the biomass of submerged macrophytes as a renewable resource [28].

Table 5 summarizes the supporting and inhibiting factors for the use of biomass from de-weeding operations in biogas plants. It is obvious that in addition to the
Table 5 Summary of arguments for the use of substrates from de-weeding operations

\begin{tabular}{|c|c|}
\hline & Sources \\
\hline \multicolumn{2}{|l|}{ Supporting factors } \\
\hline $\begin{array}{l}\text { Nutrient contents of the substrates are comparably } \\
\text { high }\end{array}$ & {$[12,13]$} \\
\hline $\begin{array}{l}\text { Storage and ensiling well possible under certain } \\
\text { conditions }\end{array}$ & {$[10,11]$} \\
\hline Substrates are essentially disposed of today & $\begin{array}{l}\text { Based on our } \\
\text { survey }\end{array}$ \\
\hline $\begin{array}{l}\text { Regionally, large quantities of the substrates are } \\
\text { harvested (e.g., Mecklenburg-Western Pomerania) }\end{array}$ & $\begin{array}{l}\text { Based on our } \\
\text { survey }\end{array}$ \\
\hline $\begin{array}{l}\text { Biogas yields are high in combination with other } \\
\text { substrates }\end{array}$ & {$[13]$} \\
\hline $\begin{array}{l}\text { In the flowing and standing water bodies there are } \\
\text { high quantities that were not harvested }\end{array}$ & $\begin{array}{l}\text { Based on our } \\
\text { survey }\end{array}$ \\
\hline \multicolumn{2}{|l|}{ Inhibitory factors } \\
\hline $\begin{array}{l}\text { The amount of harvested biomass can vary from } \\
\text { year to year }\end{array}$ & $\begin{array}{l}\text { Based on our } \\
\text { survey }\end{array}$ \\
\hline The costs of mowing and harvesting are quite high & {$[26]$} \\
\hline $\begin{array}{l}\text { Legal status of substrates from de-weeding } \\
\text { operations is not clear, especially whether they } \\
\text { are renewable resources }\end{array}$ & {$[27]$} \\
\hline $\begin{array}{l}\text { In semi-natural or natural water bodies, conflicts } \\
\text { with nature conservation can occur }\end{array}$ & $\begin{array}{l}\text { Based on our } \\
\text { survey }\end{array}$ \\
\hline $\begin{array}{l}\text { The use of the substrates can endanger the } \\
\text { approval of biogas plant }\end{array}$ & {$[27]$} \\
\hline $\begin{array}{l}\text { Cost efficiency also depends on the development of } \\
\text { new machines for mowing and harvesting }\end{array}$ & {$[26]$} \\
\hline
\end{tabular}

biomass potential, economic, administrative, and technical factors are important.

In addition, further research is needed regarding the amount of water plant growth depending on the mix of species, the seasonal fluctuation, and the ability for regeneration after de-weeding.

\section{Abbreviations}

AWGN: Amtliches Digitales Wasserwirtschaftliches Gewässernetz BadenWürttemberg; DM: Dry matter; FM: Fresh biomass; GIS: Geographic information system; LUBW: State Institute for the Environment, Measurements and Nature Conservation Baden-Württemberg; PME: Plant mass estimates; REA: Renewable Energy Act; TPME: Total plant mass estimates; WFD: European Water Framework Directive

\section{Acknowledgements}

The authors would like to thank Aline Bauer and Kai Baudis for their support in carrying out the survey, Lucie Moeller from the Helmholtz-Centre for Environmental Research, and Walter Stinner and Harald Wedwitschka from the German Biomass Research Centre (DBFZ) and Vasco Brummer formerly from the Institute for International Research on Sustainable Management and Renewable Energy for the constructive discussions of the last three years.

\section{Authors' contributions}

MR collected and sorted the publication and information material, analyzed the data from the survey, and prepared the manuscript. SR collected and analyzed the data from the survey and prepared the manuscript. WS analyzed the data from the regional example of Baden-Württemberg and prepared the manuscript in this part. $\mathrm{CH}$ contributed to the critical reading of the manuscript and provided input for the final version. AZ led the project 
and contributed to the consultations and critical reading of the manuscript All authors edited and approved the final manuscript.

\section{Authors' information}

MR is a professor and member of the Institute for Landscape and Environment (ILU) at Nürtingen-Geislingen University. SR is a researcher at the Institute for Landscape and Environment (ILU) at Nürtingen-Geislingen University. WS is a freelance consultant with the main focus on water ecology and submerged macrophytes. AZ is a senior researcher and group leader of the research group Bioprocess Engineering at the Department of Environmental Biotechnology at the Helmholtz Centre for Environmental Research $\mathrm{GmbH}$ - UFZ and professor at the University of Cooperative Education Riesa. $\mathrm{CH}$ is a Professor and Director of the Institute for International Research on Sustainable Management and Renewable Energy (ISR) at Nürtingen-Geislingen University.

\section{Funding}

The investigations that form the basis for this article were carried out within the framework of the research project "Aquatic macrophytes - Optimal ecological and economic use" (AquaMak). The "AquaMak" project is supported by the German Federal Ministry of Food, Agriculture and Consumer Protection with funds from the so-called Energy and Climate Funds (EKF) on the basis of a decision of the German Parliament (grant number 22403013). The project partners are the Helmholtz Centre for Environmental Research-UFZ, Nürtingen-Geislingen University-HfWU, and the German Biomass Research Centre-DBFZ.

\section{Availability of data and materials}

The datasets used and analyzed during the current study are available from the corresponding author on reasonable request.

\section{Ethics approval and consent to participate}

Not applicable.

\section{Consent for publication}

Not applicable.

\section{Competing interests}

The authors declare that they have no competing interests.

\section{Author details}

${ }^{1}$ Hochschule für Wirtschaft und Umwelt Nürtingen-Geislingen, Institut für Landschaft und Umwelt (ILU), Sigmaringer Strasse 14, 72622 Nürtingen, Germany. ${ }^{2}$ Büro für Ökologie und Vegetationskunde, Im Jägeracker 28, 79312 Emmendingen, Germany. ${ }^{3}$ Department Centre for Environmental Biotechnology, Helmholtz Centre for Environmental Research - UFZ, Permoserstrasse 15, 04318 Leipzig, Germany. ${ }^{4}$ Hochschule für Wirtschaft und Umwelt Nürtingen-Geislingen, Institute for International Research on Sustainable Management and Renewable Energy (ISR), Sigmaringer Strasse 14, 72622 Nürtingen, Germany.

\section{Received: 27 July 2018 Accepted: 23 May 2019}

Published online: 10 June 2019

\section{References}

1. Szarka N, Eichhorn M, Kittler R, Bezama A, Thrän D (2017) Interpreting longterm energy scenarios and the role of bioenergy in Germany. Renew Sust Energ Rev 68:1222-1233. https://doi.org/10.1016/j.rser.2016.02.016

2. Manning P, Taylor G, Hanley E (2015) Bioenergy, food production and biodiversity - an unlikely alliance? GCB Bioenergy 7:570-576. https://doi.org/ $10.1111 /$ gcbb. 12173

3. Seidel D, Busch G, Krause B, Bade C, Fessel C, Kleinn C (2015) Quantification of biomass production potentials from trees outside forests-a case study from Central Germany. BioEnergy Res 8(3):1344-1351

4. Franklin P, Dunbar M, Whitehead P (2008) Flow controls on lowland river macrophytes: a review. Sci Total Environ 400:369-378

5. Sand-Jensen K, Vindbaek Madsen T (1991) Minimum light requirements of submerged freshwater macrophytes in laboratory growth experiments. Ecol 79/3:749-764. https://doi.org/10.2307/2260665
6. Schütz W (2017) In: Moeller L, Zehnsdorf A (eds) Aquatische Makrophyten im Kontext der WRRL. Wasserpflanzenmanagement, Leipzig, pp 55-62 ISBN 978-3-944280-06-6

7. Vereecken H, Baetens J, Viane P, Mostaert F, Meire P (2006) Ecological management of aquatic plants: effects in lowland streams. Hydrobiologia 570:205-210

8. Thomas E (1975) Kampf dem zunehmenden Wasserpflanzenbewuchs in unseren Gewässern. Krautwucherungen als schwerwiegendes Gewässerschutzproblem in Fließgewässern. Wasser- und Energiewirtschaft 67:12-19

9. Baattrup-Pedersen A, Larsen SE, Riis T (2002) Long-term effect of stream management on plant communities in two Danish lowland streams. Hydrobiologia 481(1):33-45

10. Wedwitschka H, Gießmann M, Gallegos D, Rajendran PK, Stinner W (2017) In: Moeller L, Zehnsdorf A (eds) In Mischung konservieren. Wasserpflanzenmanagement, Leipzig, pp 26-31 ISBN 978-3-944280-06-6

11. Wedwitschka H, Stinner W, Moeller L, Roth S, Brummer V, Röhl M, Herbes C, Zehnsdorf A (2016) Wasserpflanzen als Substrat für Biogasanlagen praxisgerechte Silierung und Vergärung. In: Nelles M (ed) 10th Rostocker Bioenergieforum on 16th and 17th Juni 2016 of The University of Rostock: Conference proceedings, Fonts Series Umweltingenieurwesen 58. The University of Rostock, Faculty of Agricultural and Environmental Sciences, Rostock, pp 259-265

12. Zehnsdorf A, Moeller L, Stärk H-J, Auge H, Röhl M, Stinner W (2017) The study of the variability of biomass from plants of the Elodea genus from a river in Germany over a period of two hydrological years for investigating their suitability for biogas production. Energy Sustain Soc 7:15. https://doi. org/10.1186/s13705-017-0117-0

13. Moeller L, Bauer A, Wedwitschka H, Stinner W, Zehnsdorf A (2018) Crop characteristics of aquatic macrophytes for use as a substrate in anaerobic digestion plants - a study from Germany. Energies 11:3016. https://doi.org/ 10.3390/en11113016

14. Piegenschke A (2016) Ermittlung von Biomassepotenzialen submerser Makrophyten in der Niers. Bachelor thesis, Nürtingen-Geislingen-University

15. Röhl M, Roth S (2017) In: Moeller L, Zehnsdorf A (eds) Biomassepotenziale submerser Makrophyten in Deutschland. Wasserpflanzenmanagement, Leipzig, pp 6-12 ISBN 978-3-944280-06-6

16. CEN (2003) European Standard EN 14184 - water quality - guidance standard for the surveying of macrophytes in running waters. Comité Européen de Normalisation, Bruxelles

17. Kohler A, Janauer G (1995) Zur Methodik der Untersuchung von aquatischen Makrophyten in Fließgewässern. In: Ch S, Bernhard H, Klapper H (eds) Handbuch der Angewandten Limnologie VIII-1.1.3, 1,22. Ecomed, Landsberg/Lech

18. Podani J (2006) Braun-Blanquet's legacy and data analysis in vegetation science. J Veg Sci 17:113-117

19. Janauer GA, Heindl E (1998) Die Schätzsskala nach Kohler: Zur Gültigkeit der Funktion $f(y)=a x^{3}$ als Maß für die Pflanzenmenge von Makrophyten. Verh Zool-Bot Ges Österreich 135:117-128

20. Krausch H-D (1976) Die Makrophyten der mittleren Saale und ihre Biomasse Limnologica 10:57-72

21. Ölhoft H (2013) Verarbeitungsprozesse zur energetischen und stofflichen Nutzung der Elodea nuttallii. Minor thesis, Technische Universität Dresden

22. Podraza P, Brinkmann T, Evers P, von Felde D, Frost U, Klopp R, Knotte H, Kühlmann M, Kuk M, Lipka P, Nusch EA, Stengert M, Wessel M, van de Weyer K (2008) Untersuchungen zur Massenentwicklung von Wasserpflanzen in den Ruhrstauseen und Gegenmaßnahmen. In: Final report, research project for the Ministry of Environment and Conservation, Agriculture and Consumer Protection of the Federal State of North Rhine Westphalia (MUNLV)

23. Podraza P (2017) In: Moeller L, Zehnsdorf A (eds) Management von Flussstauseen im Ruhrgebiet. Wasserpflanzenmanagement, Leipzig, pp 72 80 ISBN 978-3-944280-06-6

24. Ruf J, Henning K (2009) Amtliches Digitales Wasserwirtschaftliches Gewässernetz (AWGN). LUBW, Karlsruhe http://www4.lubw.badenwuerttemberg.de/servlet/is/55787/amtliches digitales wasserwirtschaftliches_gewaessernetz.pdf?command= downloadContent\&filename=amtliches digitales wasserwirtschaftliches gewaessernetz.pdf. Accessed 3 Nov 2017

25. Landesanstalt für Umwelt (2007) Messungen und Naturschutz BadenWürttemberg. In: Überwachungsprogramme: Fließgewässer, Seen. 
Grundwasser, Karlsruhe https://www4.lubw.baden-wuerttemberg.de/servlet/ is/26923/ueberwachungsprogramme_fliessgewaesser_seen.pdf?command= downloadContent\&filename=ueberwachungsprogramme_fliessgewaesser_ seen.pdf. Accessed 3 Nov 2017. ISBN: 978-3-88251-324-0

26. Lehner B, Döll P, Alcamo J, .Henrichs T, Kaspar, F (2006) Estimating the impact of global change on flood and drought risks in Europe: a continental, integrated analysis. Clim Chang 75: 273-299. doi: https://doi. org/10.1007/s10584-006-6338-4

27. Herbes C, Brummer V, Roth S (2018) Röhl M (2018) using aquatic plant biomass from de-weeding in biogas processes - an economically viable option? Energy. Sustainability and Society 8:21. https://doi.org/10.1186/ s13705-018-0163-2

28. Wiesheu M (2017) In: Moeller L, Zehnsdorf A (eds) Alternative Substrate für Biogasanlagen. Wasserpflanzenmanagement, Leipzig, pp 43-49 ISBN 978-3944280-06-6

\section{Publisher's Note}

Springer Nature remains neutral with regard to jurisdictional claims in published maps and institutional affiliations.

Ready to submit your research? Choose BMC and benefit from:

- fast, convenient online submission

- thorough peer review by experienced researchers in your field

- rapid publication on acceptance

- support for research data, including large and complex data types

- gold Open Access which fosters wider collaboration and increased citations

- maximum visibility for your research: over $100 \mathrm{M}$ website views per year

At BMC, research is always in progress.

Learn more biomedcentral.com/submissions 